\title{
EVALUATION OF METHODS IN DETECTING VANCOMYCIN MIC AMONG MRSA ISOLATES ANDTHE CHANGES IN ACCURACY RELATED TO DIFFERENT MIC VALUES
}

Fernanda Cristina Possamai ROSSATto(1), Letícia Auler PROENÇA(1), Ana Paula BECKER(1,2), Alessandro Conrado de Oliveira SILVEIRA(1), Juliana CAIERÃO(1) \& Pedro Alves D'AZEVEDO(1)

\begin{abstract}
SUMMARY
INTRODUCTION: Methicillin-Resistant Staphylococcus aureus (MRSA) presenting reduced susceptibility to vancomycin has been associated to therapeutic failure. Some methods used by clinical laboratories may not be sufficiently accurate to detect this phenotype, compromising results and the outcome of the patient. OBJECTIVES: To evaluate the performance of methods in the detection of vancomycin MIC values among clinical isolates of MRSA. MATERIAL AND METHODS: The Vancomycin Minimal Inhibitory Concentration was determined for 75 MRSA isolates from inpatients of Mãe de Deus Hospital, Porto Alegre, Brazil. The broth microdilution (BM) was used as the gold-standard technique, as well as the following methods: E-test ${ }^{\circledR}$ strips (BioMérieux), M.I.C.E ${ }^{\circledR}$ strips (Oxoid), PROBAC ${ }^{\circledR}$ commercial panel and the automated system MicroScan ${ }^{\circledR}$ (Siemens). Besides, the agar screening test was carried out with $3 \mu \mathrm{g} / \mathrm{mL}$ of vancomycin. RESULTS: All isolates presented MIC $\leq 2 \mu \mathrm{g} / \mathrm{mL}$ for BM. E-test ${ }^{\circledR}$ had higher concordance (40\%) in terms of global agreement with the gold standard, and there was not statistical difference among E-test ${ }^{\circledR}$ and broth microdilution results. PROBAC ${ }^{\circledR}$ panels presented MICs, in general, lower than the gold-standard panels (58.66\% major errors), while M.I.C.E. ${ }^{\circledR}$ MICs were higher (67.99\% minor errors). CONCLUSIONS: For the population of MRSA in question, E-test ${ }^{\circledR}$ presented the best performance, although with a heterogeneous accuracy, depending on MIC values.
\end{abstract}

KEYWORDS: Methicillin-Resistant Staphylococcus aureus; Vancomycin; Minimal Inhibitory Concentration.

\section{INTRODUCTION}

Methicillin-resistant Staphylococcus aureus (MRSA) is one of the most important bacterial pathogens worldwide, especially in healthcare associated infections ${ }^{7}$. As MRSA is almost always multiresistant, vancomycin is the therapy of choice. In 2007, the Clinical and Laboratory Standards Institute (CLSI) determined the reduction of breakpoints for Minimal Inhibitory Concentration (MIC) of vancomycin among $S$. aureus to increase the sensitivity in detecting the non-susceptible isolates ${ }^{5}$. The apparent increase in vancomycin MIC among MRSA, observed in the last years, could represent the first step for the occurrence of fully resistant isolates. Indeed, the emergence of strains has been determined by presenting intermediate resistance (VISA) or hetero-VISA (vancomycin-intermediate $S$. aureus). Besides, increasing proportions of MRSA isolates with high MICs have been observed within the susceptible range, a phenomenon known as vancomycin MIC creep $^{8,10}$. These isolates with MIC creep have been associated with therapeutic failure $^{13,18}$, as vancomycin may be ineffective against isolates with MICs between 1 and $2 \mu \mathrm{g} / \mathrm{mL}^{8}$.

Several methods with variable sensitivity and specificity are available to determine vancomycin MIC. According to CLSI, broth microdilution $(\mathrm{BM})$ is considered the gold standard ${ }^{5}$. However, because it is timeconsuming, a considerable number of clinical laboratories do not use it as routine methodology. Other techniques have been widely used, with variable sensitivity and specificity, such as automated systems, strips with antimicrobial concentration gradient and microdilution commercial panels ${ }^{6}$. The objective of this study was to evaluate the accuracy of several methods in the characterization of vancomycin MIC among clinical MRSA isolates.

\section{MATERIAL AND METHODS}

Bacterial isolates: Seventy-five MRSA from Mãe de Deus hospital, a 400-bed general hospital in Porto Alegre, were evaluated in Southern Brazil. Methicillin resistance was first characterized by automated system (MicroScan Walk Away, Siemens ${ }^{\circledR}$ ), MRSA phenotype was confirmed by molecular methods ( $m e c \mathrm{~A}$ gene), described elsewhere ${ }^{20}$. Isolates were maintained $\left(-20^{\circ} \mathrm{C}\right)$ in $10 \%$ Skim Milk (Difco, Detroit, USA) with $10 \%$ glycerol.

Determination of Minimal Inhibitory Concentration: Vancomycin

Sponsorships: CNPq, FAPERGS.

(1) Department of Microbiology, Federal University of Health Science of Porto Alegre, Porto Alegre, RS, Brazil.

(2) Department of Microbiology, Mãe de Deus Hospital, Porto Alegre, RS, Brazil.

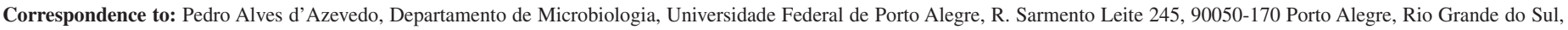
Brasil. Tel.: +55 (51) 3303-9000, Fax +55 (51) 3303-8810. E-mail: pedro_dazevedo@yahoo.com.br 
ROSSATTO, F.C.P.; PROENÇA, L.A.; BECKER, A.P.; SILVEIRA, A.C.O.; CAIERÃO, J. \& D’AZEVEDO, P.A. - Evaluation of methods in detecting Vancomycin MIC among MRSA isolates and the changes in accuracy related to different MIC values. Rev. Inst. Med. Trop. Sao Paulo, 56(6): 469-72, 2014.

MICs were determined by $\mathrm{BM}^{6}$ and by the following techniques, according to the manufacturer's instructions: E-test ${ }^{\circledR}$ strips (BioMérieux, Marcy l'Étoile, France), M.I.C.E. ${ }^{\circledR}$ strips (Oxoid, Thermo Fisher Scientific, Basingstoke, UK), MicroScan and commercial panels for MIC detection $\left(\mathrm{PROBAC}^{\circledast}\right)$. Besides, the agar dilution screening test was performed with $3 \mu \mathrm{g} / \mathrm{mL}$ of vancomycin, as proposed by BURNHAM, WEBER \& DUNNE ${ }^{1}$. A vancomycin-susceptible strain (ATCC 25923) and a positive control (Enterococcus faecalis carrying vanA gene) were used for all methodologies.

Statistical analysis: Descriptive statistics were applied, and data were evaluated by ANOVA, followed by the Tukey post hoc test. The results were processed using the Statistical Package for Social Sciences (SPSS) 17.0. Results statistically significant were considered when $p$ $<0.05$.

\section{RESULTS}

The 75 MRSA evaluated were susceptible to vancomycin with MICs $\leq 2 \mu \mathrm{g} / \mathrm{mL}$ (BM): $2 \mu \mathrm{g} / \mathrm{mL}$ (4\%), $1 \mu \mathrm{g} / \mathrm{mL}(50.66 \%), 0.5 \mu \mathrm{g} / \mathrm{mL}(42.66 \%)$, and $0.25 \mu \mathrm{g} / \mathrm{mL}(2.66 \%)$. The $\mathrm{MIC}_{50}$ and $\mathrm{MIC}_{90}$ were both $1 \mu \mathrm{g} / \mathrm{mL}$. All isolates were susceptible to vancomycin for agar dilution screening. The MicroScan panel used had four dilution points $(16,8,4$ and $2 \mu \mathrm{g} / \mathrm{mL})$ and all isolates presented MICs $\leq 2 \mu \mathrm{g} / \mathrm{mL}$.

The E-test ${ }^{\circledR}$ was statistically similar to BM $(p=0.777)$. However, PROBAC ${ }^{\circledR}$ and M.I.C.E. ${ }^{\circledR}$ were both statistically different compared to the gold standard $(p<0.001)$.

For the E-test ${ }^{\circledast}$ analysis, two approaches were used: the first one used the gross values; for the second approach, CLSI breakpoints for $\mathrm{BM}$ were used to evaluate the E-test ${ }^{\circledR}$ (i.e. an E-test MIC of 3 was, for this approach, considered $4 \mu \mathrm{g} / \mathrm{mL}$ ). This data are shown in Table 1.

The agreement among evaluated methods and BM was also evaluated, considering each MIC value to observe if the performance of the methods depended on the MIC value, as shown in Table 2.
Considerable heterogeneous performance was observed in different MIC values. In MRSA isolates with a vancomycin MIC of $0.25 \mu \mathrm{g} / \mathrm{mL}$, the E-test ${ }^{\circledR}$ and M.I.C.E. ${ }^{\circledR}$ presented values at least 1-fold higher than BM for all isolates; which was also observed in most isolates with a MIC of $0.5 \mu \mathrm{g} / \mathrm{mL}$. However, for a MIC of 1 and $2 \mu \mathrm{g} / \mathrm{mL}$, higher agreements for both strip-based methodologies (Table 2) were observed. For these methods, discordant results showed MICs 1-fold higher than BM for MIC $1 \mu \mathrm{g} / \mathrm{mL}$. On the other hand, for MIC $2 \mu \mathrm{g} / \mathrm{mL}$, all discordant results presented MICs lower than the gold standard method. Regarding the commercial panel PROBAC ${ }^{\circledR}$, better performances were observed in lower MICs $(0.25$ and $0.5 \mu \mathrm{g} / \mathrm{mL})$. For MICs 1 and $2 \mu \mathrm{g} / \mathrm{mL}$, discordance was a major concern (Table 2).

In terms of global agreement with the gold standard, the E-test ${ }^{\circledR}$ had higher concordance (40\%) and it was the only one statistically similar to $\mathrm{BM}$, followed by PROBAC ${ }^{\circledR}(36 \%)$, which had a higher number of major errors (58.66\%). Minor errors were mostly observed for M.I.C.E. ${ }^{\circledR}$ strips $(67.99 \%)$.

\section{DISCUSSION}

The therapeutic failure related to vancomycin is well established, especially regarding to MIC creeps ${ }^{13}$. Most hospitals report estimated vancomycin MICs through automated methods. However, different authors show evidence that MIC creeps are not accurately detected by automated systems ${ }^{8,9}$. The failure during vancomycin therapy is particularly associated to pharmacokinetic and pharmacodinamic characteristics of the drug, which needs a ratio area under the curve/MIC higher than 400 to obtain therapeutic success. When isolates present a MIC of $2 \mu \mathrm{g} / \mathrm{mL}$, this ratio is hard to achieve, once serum vancomycin concentration should be 15 and $20 \mu \mathrm{g} / \mathrm{mL}^{19}$.

In this study, the E-test ${ }^{\circledR}$ was, in general, the method with a higher agreement with $\mathrm{BM}$, presenting the most homogeneous performance in different MIC values. The commercial panel PROBAC ${ }^{\circledR}$ presented better performance in lower MIC data regarding these panels, which is extremely relevant, considering the absence of previous information on

Table 1

Distribution of MRSA according to MIC values and methodologies

\begin{tabular}{|c|c|c|c|c|c|}
\hline \multirow{2}{*}{ MIC ( $\mu \mathrm{g} / \mathrm{mL})$} & \multicolumn{5}{|c|}{ Methodology \% (n) } \\
\hline & Broth microdilution & PROBAC $^{\circledR}$ & E-test ${ }^{\circledR}$ & E-test ${ }^{\circledR * * * *}$ & M.I.C.E. ${ }^{\circledR}$ \\
\hline 0.25 & $2.66 \%(2)$ & $18.66 \%(14)$ & $1.33 \%(1)$ & $1.33 \%(1)$ & $1.33 \%(1)$ \\
\hline $0.38 *$ & $\mathrm{NA}^{* *}$ & $\mathrm{NA}^{* *}$ & $5.33 \%(4)$ & $\mathrm{NA}^{* *}$ & $\mathrm{NA}^{* *}$ \\
\hline 0.50 & $42.66 \%(32)$ & $68 \%(51)$ & $14.66 \%(11)$ & $20 \%(15)$ & $2.66 \%(2)$ \\
\hline $0.75^{*}$ & $\mathrm{NA}^{* *}$ & $\mathrm{NA}^{* *}$ & $25.33 \%(19)$ & NA** & NA** \\
\hline 1.00 & $50.66 \%(38)$ & $13.33 \%(10)$ & $30.66 \%(23)$ & $56 \%(42)$ & $38.66 \%(29)$ \\
\hline $1.50 *$ & $\mathrm{NA}^{* *}$ & $\mathrm{NA}^{* *}$ & $22.66 \%(17)$ & NA** & $\mathrm{NA}^{* *}$ \\
\hline \multirow[t]{2}{*}{2.00} & $4 \%(3)$ & $0 \%(0)$ & $0 \%(0)$ & $22.66 \%(17)$ & $57.33 \%(43)$ \\
\hline & $100 \%(75)$ & $100 \%(75)$ & $100 \%(75)$ & $100 \%(75)$ & $100 \%(75)$ \\
\hline
\end{tabular}

MRSA: Methicillin-resistant Staphylococcus aureus; MIC: Minimal Inhibitory Concentration; *MICs value observed only on E-test ${ }^{\circledR}$ strip; $* *$ NA $=$ not applicable; ***CLSI breakpoints for BM were used for the evaluation of E-tests ${ }^{\circledast}$ results. 


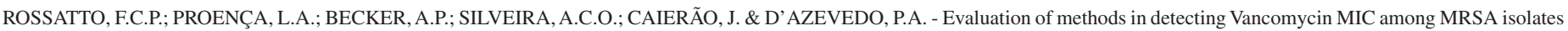
and the changes in accuracy related to different MIC values. Rev. Inst. Med. Trop. Sao Paulo, 56(6): 469-72, 2014

Table 2

Agreement (\%) among methods and BM, according to vancomycin MIC values

\begin{tabular}{|c|c|c|c|c|c|}
\hline $\begin{array}{l}\text { Broth microdilution } \\
\text { MIC }(\mu \mathrm{g} / \mathrm{mL})\end{array}$ & Methodology & Agreement $\%(n)$ & Lower MIC $\%$ (n) & 1X higher ${ }^{\# \#}$ MIC \% (n) & 2X higher ${ }^{\# \# \# ~ M I C ~ \% ~(n) ~}$ \\
\hline \multirow{3}{*}{0.25} & PROBAC $^{\circledR}$ & $50.00 \%(1)$ & $0.00 \%(0)$ & $50.00 \%(1)$ & $0.00 \%(0)$ \\
\hline & E-test ${ }^{\circledR} *$ & $0.00 \%(0)$ & $0.00 \%(0)$ & $50.00 \%(1)$ & $50.00 \%(1)$ \\
\hline & M.I.C.E. ${ }^{\circledR}$ & $0.00 \%(0)$ & $0.00 \%(0)$ & $0.00 \%(0)$ & $100.00 \%(2)$ \\
\hline \multirow{3}{*}{0.50} & PROBAC $^{\circledR}$ & $59.37 \%$ (19) & $31.25 \%(10)$ & $9.38 \%(3)$ & $0.00 \%(0)$ \\
\hline & E-test $^{\circledR} *$ & $25.00 \%(8)$ & $0.00 \%(0)$ & $56.25 \%(18)$ & $18.75 \%(6)$ \\
\hline & M.I.C.E. ${ }^{\circledR}$ & $3.12 \%(1)$ & $3.12 \%(1)$ & $28.13 \%(9)$ & $65.63 \%(21)$ \\
\hline \multirow{3}{*}{1.00} & PROBAC $^{\circledR}$ & $18.42 \%(7)$ & $81.58 \%(31)$ & $0.00 \%(0)$ & $0.00 \%(0)$ \\
\hline & E-test $^{\circledR} *$ & $55.26 \%(21)$ & $18.42 \%(7)$ & $26.32 \%(10)$ & $0.00 \%(0)$ \\
\hline & M.I.C.E. ${ }^{\circledR}$ & $47.37 \%(18)$ & $2.63 \%(1)$ & $50.00 \%(19)$ & $0.00 \%(0)$ \\
\hline \multirow{3}{*}{2.00} & PROBAC $^{\circledR}$ & $0.00 \%(0)$ & $100.00 \%(3)$ & $0.00 \%(0)$ & $0.00 \%(0)$ \\
\hline & E-test $^{\circledR} *$ & $33.33 \%(1)$ & $66.67 \%(2)$ & $0.00 \%(0)$ & $0.00 \%(0)$ \\
\hline & M.I.C.E. ${ }^{\circledR}$ & $66.67 \%(2)$ & $33.33 \%(1)$ & $0.00 \%(0)$ & $0.00 \%(0)$ \\
\hline \multirow{3}{*}{ Global agreement } & PROBAC $^{\circledR}$ & $36.00 \%(27)$ & $58.66 \%(44)$ & $5.33 \%(4)$ & $0.00 \%(0)$ \\
\hline & E-test $^{\circledR} *$ & $40.00 \%(30)$ & $12.00 \%$ (9) & $38.66 \%$ (29) & $9.33 \%(7)$ \\
\hline & M.I.C.E. ${ }^{\circledR}$ & $28.00 \%(21)$ & $4.00 \%(3)$ & $37.33 \%(28)$ & $30.66 \%(23)$ \\
\hline
\end{tabular}

*CLSI breakpoints for BM were used for the evaluation of E-tests ${ }^{\circledR}$ results; ${ }^{*}$ MICs were defined as lower than the BM; ${ }^{\#}$ MICs were defined as one-fold dilution higher than the BM; ${ }^{\prime \prime \prime}$ MICs were defined as two-fold dilution higher than the BM.

the performance of this method. To the authors' knowledge, this is the first study to evaluate the accuracy of MICs determined by PROBAC ${ }^{\circledR}$ panels.

On the other hand, M.I.C.E. ${ }^{\circledR}$ had better performance with higher MICs. Global agreement of M.I.C.E. ${ }^{\circledR}(28 \%)$ was considerably lower than that observed by CAMPANA et al. (2011) (76.3\%). Besides, MUSHTAQ et al. (2010) observed elevated rates of agreement between the strips (M.I.C.E. ${ }^{\circledR}$ and E-test ${ }^{\circledR}$ ), concluding that both are appropriate for clinical laboratory use. In this study, the low global agreement of M.I.C.E. ${ }^{\circledR}$ strips does not point them as accurate methods.

VAN HAL et al. (2012), in his meta-analysis, showed no statistical difference between mortality associated with infections caused by $S$. aureus strains and vancomycin MIC of $1.5 \mu \mathrm{g} / \mathrm{mL}$ and $1 \mu \mathrm{g} / \mathrm{mL}$. However, mortality associated with strains presenting MIC $2 \mu \mathrm{g} / \mathrm{mL}$ and $1.5 \mu \mathrm{g} /$ $\mathrm{mL}$ was statistically different. Therefore, the interpretation of M.I.C.E. ${ }^{\circledR}$ results is compromised, once it does not present the $1.5 \mu \mathrm{g} / \mathrm{mL}$ value of MIC. So, the M.I.C.E. ${ }^{\circledR}$ MIC of $2 \mu \mathrm{g} / \mathrm{mL}$ may, in fact, represent $1.5 \mu \mathrm{g} /$ $\mathrm{mL}$ or $2 \mu \mathrm{g} / \mathrm{mL}$, which could lead to therapeutic failure.

According to SWENSON et al. (2009) and RYBAC et al. (2013), the E-test ${ }^{\circledR}$ and MicroScan lead to a higher BM of MIC 1-fold. CDC recommends that the clinical laboratory should define an algorithm to determine which additional tests would be necessary to confirm an $S$. aureus as having reduced susceptibility to vancomycin. This algorithm should consider characteristics of patients and resources available in the clinical laboratory ${ }^{3}$. As MIC average of population may affect performance of tests, it should be considered when choosing alternative methodologies for broth microdilution.
For the MRSA isolates tested, the E-test ${ }^{\circledR}$ presented the best performance. Even though, overestimated MIC, also described by other authors, compromises the accuracy of the method. Nevertheless, these non-accurate MICs represent minor errors, which have lower impact on the treatment of patients, compared to major errors. So, this data support the use of the E-test ${ }^{\circledR}$ as a rapid and easy test.

This study has some limitations. First, the reduced number of isolates could have compromised the statistical analysis. Second, the MRSA population tested presented low MICs; studies with a different population of MRSA must be conducted to evaluate the performance of methods in strains with higher chances of leading to therapeutic failures and determining if differences in performance would also be observed.

Another point of concern is that MIC values may suffer alterations after cryopreservation. EDWARDS et al. (2012) demonstrated that MICs from automated systems and the E-test ${ }^{\circledR}$ were significantly lower after cryopreservation, if compared with those from the E-test ${ }^{\circledR}$ analysis, at the time of isolation, either for vancomycin and daptomycin. SCHAUMBURG et al. (2014) also pointed out that the prevalence of vancomycin MIC creeps may be underestimated because of the cryopreservation effect. Therefore, vancomycin MIC creeps might be lost after cryoconservation ${ }^{8,16}$. This variable was not considered as the study population. Further studies must be designed to reinforce previous observations.

Monitoring the occurrence of $S$. aureus with reduced susceptibility to vancomycin is a subject. For the population of MRSA tested, the E-test ${ }^{\circledR}$ presented the best performance, although with heterogeneous accuracy, 
ROSSATTO, F.C.P.; PROENÇA, L.A.; BECKER, A.P.; SILVEIRA, A.C.O.; CAIERÃO, J. \& D’AZEVEDO, P.A. - Evaluation of methods in detecting Vancomycin MIC among MRSA isolates and the changes in accuracy related to different MIC values. Rev. Inst. Med. Trop. Sao Paulo, 56(6): 469-72, 2014.

depending on MIC values. Thus, the choice of method to determine MIC values must take into consideration costs, conditions of the clinical laboratory and the characteristics of the $S$. aureus populations evaluated.

\section{RESUMO}

\section{Avaliação de métodos na detecção da MIC de vancomicina e mudanças na acurácia relacionada a diferentes valores de MIC}

INTRODUÇÃO: Staphylococcus aureus resistente à meticilina (MRSA) apresentando suscetibilidade reduzida à vancomicina tem sido associado à falha terapêutica. Alguns métodos utilizados por laboratórios clínicos podem não ser suficientemente precisos para detectar este fenótipo, comprometendo os resultados e o desfecho do paciente. OBJETIVOS: Avaliar o desempenho de métodos na detecção dos valores de MIC de vancomicina entre isolados clínicos de MRSA. MATERIAIS E MÉTODOS: Determinamos a Concentração Inibitória Mínima de Vancomicina para 75 MRSA isolados de pacientes do Hospital Mãe de Deus, Porto Alegre, Brasil. Utilizamos a microdiluição em caldo como técnica padrão-ouro e os seguintes métodos: tiras de E-test ${ }^{\circledR}$ (BioMérieux), tiras M.I.C.E ${ }^{\circledR}$ (Oxoid), painel comercial da PROBAC ${ }^{\circledR} \mathrm{e}$ sistema automatizado MicroScan ${ }^{\circledR}$ (Siemens). Além disso, foi realizado o teste de triagem em ágar com $3 \mu \mathrm{g} / \mathrm{mL}$ de vancomicina. RESULTADOS: Todos os isolados apresentaram MIC $\leq 2 \mu \mathrm{g} / \mathrm{mL}$. Não houve diferença estatística entre os resultados do E-test ${ }^{\circledR}$ e da microdiluição em caldo. $\mathrm{O}$ painel da PROBAC ${ }^{\circledR}$ apresentou MICs, em geral, menores que o padrãoouro (58,66\% de erros maiores), enquanto que as MICs pelo M.I.C.E. ${ }^{\circledR}$ foram maiores (67,99\% de erros menores). CONCLUSÕES: Para nossa população de MRSA, E-test ${ }^{\circledR}$ apresentou o melhor desempenho, embora com uma acurácia heterogênea, dependendo dos valores da MIC.

\section{ACKNOWLEDGMENTS}

The authors would like to thank CNPq, FAPERGS for their financial support.

\section{REFERENCES}

1. Burnham CD, Weber CJ, Dunne WM Jr. Novel screening agar for detection of vancomycinnonsusceptible Staphylococcus aureus. J Clin Microbiol. 2010;48:949-51.

2. Campana EH, Carvalhaes CG, Barbosa PP, Machado AMO, Paula AM, Gales AC. Avaliação das metodologias M.I.C.E. ${ }^{\otimes}$, Etest ${ }^{\circledR}$ e microdiluição em caldo para determinação da CIM em isolados clínicos. J Bras Patol Med Lab. 2011;47:157-64.

3. Centers for Disease Control and Prevention. Interim guidelines for prevention and control of staphylococcal infection associated with reduced suscetibility to vancomycin. MMWR Morb Mortal Wkly Rep. 1997;46:626-8.

4. Centers for Disease Control and Prevention. Staphylococcus aureus resistent to vancomycin - United States, 2002. MMWR Morb Mortal Wkly Rep. 2002;51:565-7.

5. Clinical Laboratory Standards Institute. Performance Standards for Antimicrobial Susceptibility Testing: Seventeenth Informational Supplement. CLSI. 2007;27:113.

6. Clinical Laboratory Standards Institute. Performance Standards for Antimicrobial Susceptibility Testing: Twentieth Informational Supplement. CLSI document M100-S20. 2010;31:73-4.

7. Dulon M, Haamann F, Peters C, Schablon A, Nienhaus A. MRSA prevalence in European healthcare settings: a review. BMC Infect Dis. 2011;11:138.
8. Edwards B, Milne K, Lawes T, Cook I, Robb A, Gould IM. Is vancomycin MIC "creep" method dependent? Analysis of methicillin-resistant Staphylococcus aureus susceptibility trends in blood isolates from North East Scotland from 2006 to 2010. J Clin Microbiol. 2012;50:318-25.

9. Golan Y, Baez-Giangreco C, O'Sullivan C, Snydman DR. Trends in vancomycin susceptibility among consecutive MRSA isolates. Abstracts of the forty-fourth annua meeting of the Infectious Diseases Society of America; 2006; Toronto, Ontario, Canada. Alexandria. Virginia: Infectious Diseases Society of America; 2006. p. 238 Abstract LB-11.

10. Joana S, Pedro P, Elsa G, Filomena M. Is vancomycin MIC creep a worldwide phenomenon? Assessment of $S$. aureus vancomycin MIC in a tertiary university hospital. BMC Res Notes. 2013;6:65.

11. Milstone AM, Carroll KC, Ross T, Shangraw KA, Perl TM. Community-associated methicillin-resistant Staphylococcus aureus strains in pediatric intensive care unit. Emerg Infect Dis. 2010;16:647-55

12. Mushtaq S, Warner M, Cloke J, Afzal-Shah M, Livermore DM. Performance of the Oxoid M.I.C.Evaluator ${ }^{\mathrm{TM}}$ Strips compared with the Etest ${ }^{\circledR}$ assay and BSAC agar dilution. J Antimicrob Chemother. 2010;65:1702-11.

13. Nadarajah R, Post LR, Liu C, Miller SA, Sahm DF, Brooks GF. Detection of vancomycinintermediate Staphylococcus aureus with the updated Trek-Sensititre System and the MicroScan System: comparison with results from the conventional Etest and CLSI standardized MIC methods. Am J Clin Pathol. 2010;133:844-8.

14. Oliveira GA, Dell'Aquila AM, Masiero RL, Levy CE, Gomes MS, Cui L, et al. Isolation in Brazil of nosocomial Staphylococcus aureus with reduced susceptibility to vancomycin. Infect Control Hosp Epidemiol. 2001;22:443-8.

15. Rybak MJ, Vidaillac C, Sader HS, Rhomberg PR, Salimnia H, Briski LE, et al. Evaluation of vancomycin susceptibility testing for methicillin-resistant Staphylococcus aureus: comparison of Etest and three automated testing methods. J Clin Microbiol 2013;51:2077-81.

16. Schaumburg F, Idelevich EA, Peters G, Mellmann A, von Eiff C, Becker K, et al. Trends in antimicrobial non-susceptibility in methicillin-resistant Staphylococcus aureus from Germany (2004-2011). Clin Microbiol Infect. 2014. DOI: 10.1111/1469-0691.12519.

17. Swenson JM, Anderson KF, Lonsway DR, Thompson A, McAllister SK, Limbago BM, et al. Accuracy of commercial and reference susceptibility testing methods for detecting vancomycin-intermediate Staphylococcus aureus. J Clin Microbiol. 2009;47:2013-7.

18. Tenover FC, Moellering RC. The rationale for revising the Clinical and Laboratory Standards Institute vancomycin minimal inhibitory concentration interpretive criteria for Staphylococcus aureus. Clin Infect Dis. 2007;44:1208-15.

19. Van Hal SJ, Lodise TP, Paterson DL. The clinical significance of vancomycin minimum inhibitory concentration in Staphylococcus aureus infections: a systematic review and meta-analysis. Clin Infect Dis. 2012;54:755-71.

20. Vannuffel P, Laterre P, Bouyer M, Gigi J, Vandercam B, Reynaert M, et al. Rapid and specific molecular identification of methicillin-resistant Staphylococcus aureus in endotracheal aspirates from mechanically ventilated patients. J Clin Microbiol. 1998:36:2366-8

21. Vaudaux P, Huggler E, Bernard L, Ferry T, Renzoni A, Lew DP. Underestimation of vancomycin and teicoplanin MICs by broth microdilution leads to underdetection of glycopeptide-intermediate isolates of Staphylococcus aureus. Antimicrob Agents Chemother. 2010;54:3861-70

22. Walsh TR, Bolmström A, Qwärnström A, Ho P, Wootton M, Howe R, et al. Evaluation of current methods for detection of staphylococci with reduced susceptibility to glycopeptides. J Clin Microbiol. 2001;39:2439-44.

Received: 29 January 2014

Accepted: 31 March 2014 